Check for updates

Cite this: RSC Adv., 2017, 7, 26019

Received 9th March 2017

Accepted 8th May 2017

DOI: $10.1039 / \mathrm{c} 7 \mathrm{ra02849k}$

rsc.li/rsc-advances

\section{Addition of iron oxides in sediments enhances 2,3,4,5-tetrachlorobiphenyl (PCB 61) dechlorination by low-voltage electric fields}

\begin{abstract}
Xiaoping Liu, ${ }^{a}$ Hui Wan, ${ }^{a}$ Yuzhou Xue, ${ }^{a}$ Chunhua Feng (D) *ab and Chaohai Wei ${ }^{\text {ab }}$
Despite the growing interest in exploiting low-voltage electric fields for bioremediation of chlorinated contaminants, little information is known about whether iron-rich minerals, naturally abundant components in environments, affect bioelectrochemical dechlorination. Here, we made the first attempt to investigate the role of iron oxides on the dechlorination of polychlorinated biphenyls in a sedimentbased bioelectrochemical reactor (BER) poised with a potential of $-0.50 \mathrm{~V}$ vs. SCE (saturated calomel electrode). We found that the addition of iron oxides significantly enhanced the rate and extent of 2,3,4,5-tetrachlorobiphenyl (PCB 61) transformation. Analysis of the bacterial structures suggested that the key species detected in the BERs were genera Geobacter and Desulfovibrio, well-known dissimilatory iron-reducing bacteria (DIRB) that were more dominant when iron oxides (e.g., $\alpha-\mathrm{Fe}_{2} \mathrm{O}_{3}$ ) were added. A positive correlation between the rate constant of PCB 61 reduction and the biogenic adsorbed Fe(॥) concentration suggests that DIRB-induced Fe(॥) should be critical for enhancing PCB dechlorination in the system.
\end{abstract}

\section{Introduction}

Polychlorinated biphenyls (PCBs), previously widely-used flameretardants and oxidation-resistant materials in electric and electronic equipment, are recognized as priority organic pollutants by the EPA (http://nlquery.epa.gov) due to their persistence in the environment, bioaccumulation in human and animal fatty tissues, and their potential for immune system damage and carcinogenicity. ${ }^{\mathbf{1 , 2}}$ PCBs have been distinctly detected in anoxic subsurface environments (e.g., aquatic sediments and soils) in the towns of Longtang and Guiyu, two electronic waste recycling sites in Guangdong province, South China., ${ }^{3,4}$ The search for cost-effective and environmentally sustainable in situ bioremediation methods is being made by both academia and industry, to clean up the contaminated sites. In recent years, the application of low-voltage electrical fields to anaerobic digestion systems for stimulating the bioremediation of chlorinated contaminants has become an intriguing alternative to the traditional biological approach owing to the controlled delivery of electrons in support of biodegradative metabolisms. ${ }^{5,6}$

\footnotetext{
${ }^{a}$ The Key Lab of Pollution Control and Ecosystem Restoration in Industry Clusters, Ministry of Education, School of Environment and Energy, South China University of Technology, Guangzhou 510006, PR China. E-mail: chfeng@scut.edu.cn; Fax: +8620-39380588; Tel: +86-20-39380588

${ }^{b}$ Guangdong Provincial Engineering and Technology Research Center for Environmental Risk Prevention and Emergency Disposal, South China University of Technology, Guangzhou 510006, PR China
}

Despite the increasing attention paid to the role of electrical fields in enhancing bioremediation, the related investigations on dechlorination of chlorinated pollutants (especially PCBs) are in the infancy stage, as few studies consider whether and how the prevalence and co-existence of other active compounds in the environments affect the bioelectrochemical dechlorination. For example, the sediments and soils in South China naturally contain iron-rich minerals. ${ }^{7}$ Of particular interest is whether the availability of iron oxides promotes, retards, or has no impact on the dechlorination of PCBs in the bioelectrochemical system (BES). In natural environments, iron oxides, on one hand, should inhibit the microbial reduction of contaminants owing to their competition as terminal electron acceptors; ${ }^{8}$ they, on the other hand, should facilitate reduction via the formation of highly reactive surface complexes with $\mathrm{Fe}(\mathrm{II}) .{ }^{\mathbf{9}, 10}$ The in situ reduction of PCBs can be more complicated by the presence of iron oxides and electric fields. Many possible reactions may take place in this system, including biological reactions of $\mathrm{PCB}$ dechlorination and dissimilatory iron reduction with acetate as the electron donor; abiotic reactions related to the reduction of PCBs by biogenic adsorbed Fe(II) or cathode; and bioelectrochemical reactions of PCB dechlorination and acetate oxidation with the bacteria as the "biocatalysts".

In the present study, we attempt to investigate how the presence of iron oxides affects the dechlorination of PCBs in a sediment-based bioelectrochemical reactor (BER) with a poised potential of $-0.50 \mathrm{~V}$ ( $v s$. SCE). Efforts are also made to understand the possible mechanisms governing PCB dechlorination in the system by analyzing the kinetics data as well as the 
bacterial composition data and comparing them with those obtained from the reference reactors (including the BER without the amendment of iron oxides, the open-circuit reactors with and without the amendment of iron oxides, and the killedcell reactor). Previous reports have shown that light PCBs (e.g., tetra-CBs, tri-CBs) are dominant congeners in the sediments/ soils of South China. ${ }^{11-13}$ As one of the tetra-CBs, PCB 61 (2,3,4,5-tetrachlorobiphenyl) was thus chosen as the model congener subject to anaerobic dechlorination in the BERs. It is also a widely investigated congener in the literature, ${ }^{14-16}$ because it is featured with ortho-, para- and meta-position of chlorine atoms, a characteristic favorable for being studied for the dechlorination pathways.

\section{Material and methods}

\subsection{Synthesis of iron oxides}

The different iron oxides were synthesized according to the method as previously described. ${ }^{17}$ Briefly, synthesis of goethite $(\alpha-\mathrm{FeOOH})$ started from the dissolution of $20.2 \mathrm{~g} \mathrm{Fe}\left(\mathrm{NO}_{3}\right) \cdot 9 \mathrm{H}_{2} \mathrm{O}$ in $0.45 \mathrm{~mol} \mathrm{~L}^{-1} \mathrm{KOH}$ solution $(1000 \mathrm{~mL})$, which was refluxed at $70{ }^{\circ} \mathrm{C}$ for $60 \mathrm{~h}$. Lepidocrocite $(\gamma$-FeOOH$)$ was prepared by mixing three solutions including $50 \mathrm{~g} \mathrm{~L}^{-1} \mathrm{FeCl}_{2} \cdot 4 \mathrm{H}_{2} \mathrm{O}(400 \mathrm{~mL}), 350 \mathrm{~g}$ $\mathrm{L}^{-1}\left(\mathrm{CH}_{2}\right)_{6} \mathrm{~N}_{4}(80 \mathrm{~mL})$, and $87.5 \mathrm{~g} \mathrm{~L}^{-1} \mathrm{NaNO}_{2}(80 \mathrm{~mL})$, which was subsequently aged at $65{ }^{\circ} \mathrm{C}$ for $3 \mathrm{~h}$. Hematite $\left(\alpha-\mathrm{Fe}_{2} \mathrm{O}_{3}\right)$ was obtained by sintering lepidocrocite powder at $420{ }^{\circ} \mathrm{C}$ for $2 \mathrm{~h}$. Maghemite $\left(\gamma-\mathrm{Fe}_{2} \mathrm{O}_{3}\right)$ was synthesized by mixing $500 \mathrm{~mL}$ of $0.2 \mathrm{~mol} \mathrm{~L}^{-1} \mathrm{FeCl}_{2}, 100 \mathrm{~mL}$ of $2 \mathrm{~mol} \mathrm{~L}^{-1}\left(\mathrm{CH}_{2}\right)_{6} \mathrm{~N}_{4}, 100 \mathrm{~mL}$ of $1.25 \mathrm{~mol} \mathrm{~L}^{-1} \mathrm{NaNO}_{3}$ solution.

\subsection{BER construction and operation}

The typical two-chamber BERs were used as we described previously. ${ }^{18}$ The two chambers were separated by a cationexchange membrane (Zhejiang Qianqiu Group Co., Ltd. China), with each having a volume of $210 \mathrm{~mL}$. Two pieces of graphite felts $(4.5 \mathrm{~cm} \times 4.5 \mathrm{~cm} \times 0.5 \mathrm{~cm})$ were used as working electrode and counter electrode, placed vertically in each chamber, respectively. Both of the two electrodes were connected to a CHI1000C potentiostat (Chenhua Corporation, Shanghai, China) by using a titanium wire $(0.6 \mathrm{~mm}$ in diameter). One chamber (denoted as the working chamber) was filled with conductive graphite granules and sediments $(50 \mathrm{~mL})$, making its effective volume reduce to $180 \mathrm{~mL}$. The graphite granules with diameters from 3 to $5 \mathrm{~mm}$ (Beijing Sanye Co. Ltd, China) were cleaned by immersion in $37 \% \mathrm{HCl}$ solution for $24 \mathrm{~h}$, followed by a thorough rinse with deionized water until the filtrate $\mathrm{pH}$ reaching 7.0. The sediment sample was taken from $40 \mathrm{~cm}$ below the surface water of a river $\left(23^{\circ} 36^{\prime} 12.30^{\prime \prime} \mathrm{N}\right.$, $113^{\circ} 04^{\prime} 38.84^{\prime \prime} \mathrm{E}$ ) in Longtang town (Qingyuan, Guangdong, China), an electronic waste recycling site that has been operating for several decades. The selected sediment was characterized with: $\mathrm{pH}$ value, 6.68; conductivity, $12.46 \mathrm{mS} \mathrm{cm}^{-1}$; organic matter content, $14.52 \mathrm{wt} \%$; cation exchange capacity, $12.7 \mathrm{cmol} \mathrm{kg}^{-1}$; total iron content, $28 \mathrm{~g} \mathrm{~kg}^{-1}$; and the dominant iron oxide, $\alpha-\mathrm{Fe}_{2} \mathrm{O}_{3}$. Prior to use, it was dried anaerobically at room temperature and passed through a 100 mesh sieve. The basal medium used in the working chamber contained: $3.0 \mathrm{~g}$ $\mathrm{L}^{-1} \mathrm{Na}_{2} \mathrm{CO}_{3}, 0.6 \mathrm{~g} \mathrm{~L}^{-1} \mathrm{Na}_{2} \mathrm{HPO}_{4}, 0.5 \mathrm{~g} \mathrm{~L}^{-1} \mathrm{NH}_{4} \mathrm{Cl}, 0.25 \mathrm{~g} \mathrm{~L}^{-1}$ cysteine- $\mathrm{HCl} \cdot \mathrm{H}_{2} \mathrm{O}, 0.25 \mathrm{~g} \mathrm{~L}^{-1} \mathrm{Na}_{2} \mathrm{~S} \cdot 9 \mathrm{H}_{2} \mathrm{O}, 0.001 \mathrm{~g} \mathrm{~L}^{-1}$ resazurin, $8.4 \mathrm{~g} \mathrm{~L}^{-1} \mathrm{NaCl}, 3.95 \mathrm{~g} \mathrm{~L}^{-1} \mathrm{MgCl}_{2} \cdot 6 \mathrm{H}_{2} \mathrm{O}, 0.27 \mathrm{~g} \mathrm{~L}^{-1} \mathrm{KCl}, 0.05 \mathrm{~g}$ $\mathrm{L}^{-1} \mathrm{CaCl}_{2} \cdot 2 \mathrm{H}_{2} \mathrm{O}, 10 \mathrm{~mL}$ of vitamin; ${ }^{19} 10 \mathrm{~mL}$ of trace element solutions. ${ }^{19}$ The same medium except vitamin and trace element solutions was used in the counter chamber.

The BER was operated at $30{ }^{\circ} \mathrm{C}$ in a three-electrode mode, with the saturated calomel electrode (SCE) placed into the working chamber as the reference electrode. It should be noted that all the potentials reported throughout this study were referred to SCE, if not otherwise stated. The potential poised to the working electrode was set to $-0.50 \mathrm{~V}$, similar potential used in previous studies concerning dechlorination stimulated by electric fields. ${ }^{20,21}$ This potential was selected mainly based on the consideration that it is high enough to avoid electrolysis of water to generate hydrogen and low enough to possibly stimulate the dechlorinating bacteria serving as an energy source. PCB 61 was spiked to the sediment in the working chamber with a desired concentration of $100 \mu \mathrm{mol} \mathrm{kg}{ }^{-1}$ (dry sediment). Acetate $\left(20 \mathrm{mmol} \mathrm{L}^{-1}\right)$ was repeatedly amended to the working chamber at the sampling intervals (i.e., every 20 days). The iron oxide, $\alpha-\mathrm{Fe}_{2} \mathrm{O}_{3}\left(4 \mathrm{~g} \mathrm{~L}^{-1}\right)$ was also introduced to the working chamber to investigate its effect on PCB dechlorination. Hematite was selected as the model iron oxide and data analysis, because it dominates in the sediments/soils in South China, a tropical and warm temperate region. Four reference experiments were conducted simultaneously: a closed-circuit BER $(-0.50 \mathrm{~V})$ in the absence of hematite, open-circuit reactors with and without the addition of $\alpha-\mathrm{Fe}_{2} \mathrm{O}_{3}$, and an experiment with the sterilized sediment. Duplicate reactors were run for each experiment. For comparisons, the BERs with the addition of $\alpha$-FeOOH, $\gamma$-FeOOH, or $\gamma-\mathrm{Fe}_{2} \mathrm{O}_{3}$ were also operated.

\subsection{Analysis of PCBs' and biogenic Fe(II) concentrations}

Duplicate enrichments were sampled every 20 days to quantify the concentrations of PCB 61 and its metabolites. Before sampling, the reactors were vigorously hand-shaken for five minutes at the aseptic operation table, and two mL of the slurry was withdrawn using a sterilized syringe. To correct for the extraction efficiency, one $\mathrm{mL}$ of $4 \mathrm{mg} \mathrm{L}^{-1} \mathrm{PCB} 166$ in hexane was added to the dried sediment sample as a surrogate standard. The samples containing the surrogate were ultrasonically extracted with $15 \mathrm{~mL}$ of $1: 1$ hexane-acetone mixture for $15 \mathrm{~min}$, and then centrifuged at $2000 \mathrm{rpm}$ for $5 \mathrm{~min}$. These extraction procedures were repeated three times. Eventually, the extracted supernatants were mixed in a bottle and rinsed with $30 \mathrm{~mL}$ of $1: 1$ hexane-dichloromethane mixture after evaporation of acetone. The extracts were purified using chromatography column with anhydrous $\mathrm{Na}_{2} \mathrm{SO}_{4}$, acidic silicon powder, neutral silicon powder (80-100 mesh) and glass wool to remove residual water and particulates. Subsequently, the samples were concentrated to $1 \mathrm{~mL}$ at $30{ }^{\circ} \mathrm{C}$ under nitrogen by using HGC-12A nitrogen evaporator (Nade Scientific Instrument Co., Ltd, China). 
The PCB congeners were identified and quantified by the GCMS-QP2010 instrument (Shimadzu, Japan) equipped with a DB-5ms capillary GC column $(0.25 \mathrm{~mm} \times 30 \mathrm{~m})$. The oven temperature was programmed to start at $50{ }^{\circ} \mathrm{C}$ for $2 \mathrm{~min}$, rise to $180^{\circ} \mathrm{C}$ at a rate of $20^{\circ} \mathrm{C} \mathrm{min}-1$, and further rise to $280{ }^{\circ} \mathrm{C}$ by $15^{\circ} \mathrm{C} \mathrm{min}^{-1}$, at which temperature it was held for $5 \mathrm{~min}$. Finally, the temperature was increased to $290{ }^{\circ} \mathrm{C}$ within $1 \mathrm{~min}$ and held for $5 \mathrm{~min}$. Helium was used as the carrier gas at a flow of $1.2 \mathrm{~mL}$ $\min ^{-1}$. The one $\mu \mathrm{L}$ extract samples were injected into the GC port in a splitless mode at $270{ }^{\circ} \mathrm{C}$ injector temperature. The qualitative and quantitative determination methods for standard samples were developed using selected ion scanning module. Matching the obtained GC retention times against authentic standards, PCB 61 and its dechlorination products, PCB 23 (2,3,5-CB), PCB 29 (2,4,5-CB) were identified. The relative molar distribution of congeners was determined from the eight-point calibration curves. The concentration of total biogenic $\mathrm{Fe}(\mathrm{II})$ was determined by extracting $\mathrm{Fe}(\mathrm{II})$ from the sediment slurry using $0.5 \mathrm{~mol} \mathrm{~L}^{-1} \mathrm{HCl}$ for $1.5 \mathrm{~h},{ }^{22}$ followed by analysis using the 1,10-phenanthroline colorimetric method. ${ }^{23}$ The removal of the solid using a $0.22 \mu \mathrm{m}$ syringe filter was applied before the determination of concentrations of dissolved $\mathrm{Fe}(\mathrm{II})$ and $\mathrm{Fe}$ (III). The concentration of total dissolved $\mathrm{Fe}$ was measured after adding $10 \mathrm{wt} \% \mathrm{OHNH}_{3} \mathrm{Cl}$ to reduce $\mathrm{Fe}(\mathrm{III})$ to $\mathrm{Fe}(\mathrm{II})$. The same 1,10-phenanthroline colorimetric method was used to quantify the concentration of aqueous Fe(II). The dissolved Fe(III) content was obtained by subtracting the concentration of dissolved Fe(II) from that of total dissolved Fe, and the biogenic adsorbed Fe(II) content was calculated as the concentration difference between the total $\mathrm{Fe}(\mathrm{II})$ and dissolved $\mathrm{Fe}(\mathrm{II})$.

\subsection{Microbial community analysis}

The microbial DNA was extracted from the sample using HiPure Soil DNA Mini Kit (Magen, China) according to the manufacturer's instruction. The extracted DNA was amplified by polymerase chain reaction (PCR) using primers 341F: CCTAYGGGRBGCASCAG and 806R: GGACTACNNGGGTATCTAAT targeting the hypervariable V3-V4 regions of bacterial $16 \mathrm{~S}$ rRNA gene. Polymerase chain reaction (PCR) amplifications were performed in a $50 \mu \mathrm{L}$ reaction mixture containing $1.5 \mu \mathrm{L}$ of each primer, $5 \mu \mathrm{L}$ of dNTPs ( $2 \mathrm{mM}), 3 \mu \mathrm{L}$ of MgSO4 $(25 \mathrm{mM}), 5$ $\mu \mathrm{L}$ of $10 \times$ KOD buffer, $1 \mu \mathrm{L}$ of KOD enzyme, $1 \mu \mathrm{L}$ of template DNA and $33.5 \mu \mathrm{L}$ of nuclease-free water. The PCR cycling was carried out in a PCR thermal cycler EASTWIN ETC-811 (Eastwin Life Sciences Inc., China). Thermal cycling conditions were as follows: an initial denaturing step at $94{ }^{\circ} \mathrm{C}$ for 2 min and 20 cycles of denaturing at $98^{\circ} \mathrm{C}$ for $10 \mathrm{~s}$, annealing at $62^{\circ} \mathrm{C}$ for $30 \mathrm{~s}$ and extension at $68^{\circ} \mathrm{C}$ for $30 \mathrm{~s}$; for the last cycling program, the final extension step was held at $68{ }^{\circ} \mathrm{C}$ for $5 \mathrm{~min}$.

The PCR products of each sample were purified and quantified by a QuantiFluor ${ }^{\mathrm{TM}}$ fluorometer (Promega, Madison, USA). The PCR products with equal DNA content for each sample were pooled and sequenced using the Miseq2500 platform PE250 (Illumina, San Diego, USA). For quality control, the dirty reads containing adapters or low quality bases were removed. The filtered reads were then assembled into tags according to overlap between paired-end reads with more than $10 \mathrm{bp}$ overlap, and less than $2 \%$ mismatch. The software Mothur (v.1.34.0) was used to remove the redundant tags to get unique tags. The obtained unique tags were then used to calculate the abundance. The Principal Component Analysis (PCA) was used to reflect the microbial compositional differences and relationships between samples using the $\mathrm{R}$ package.

\section{Results and discussion}

\subsection{The amendment of $\alpha-\mathrm{Fe}_{2} \mathrm{O}_{3}$ promotes dechlorination of PCBs in the sediment-based BERs}

To understand the effects of electrochemical stimulation and iron oxides on the transformation of PCBs in the sedimentbased BERs, the kinetics of PCB 61 reduction were investigated in the BERs poised at a potential of $-0.50 \mathrm{~V}$ with and without the addition of $\alpha-\mathrm{Fe}_{2} \mathrm{O}_{3}$, the open-circuit reference reactors with and without the addition of $\alpha-\mathrm{Fe}_{2} \mathrm{O}_{3}$, and the killed-cell reference reactor (Fig. 1a). Under the sterilized

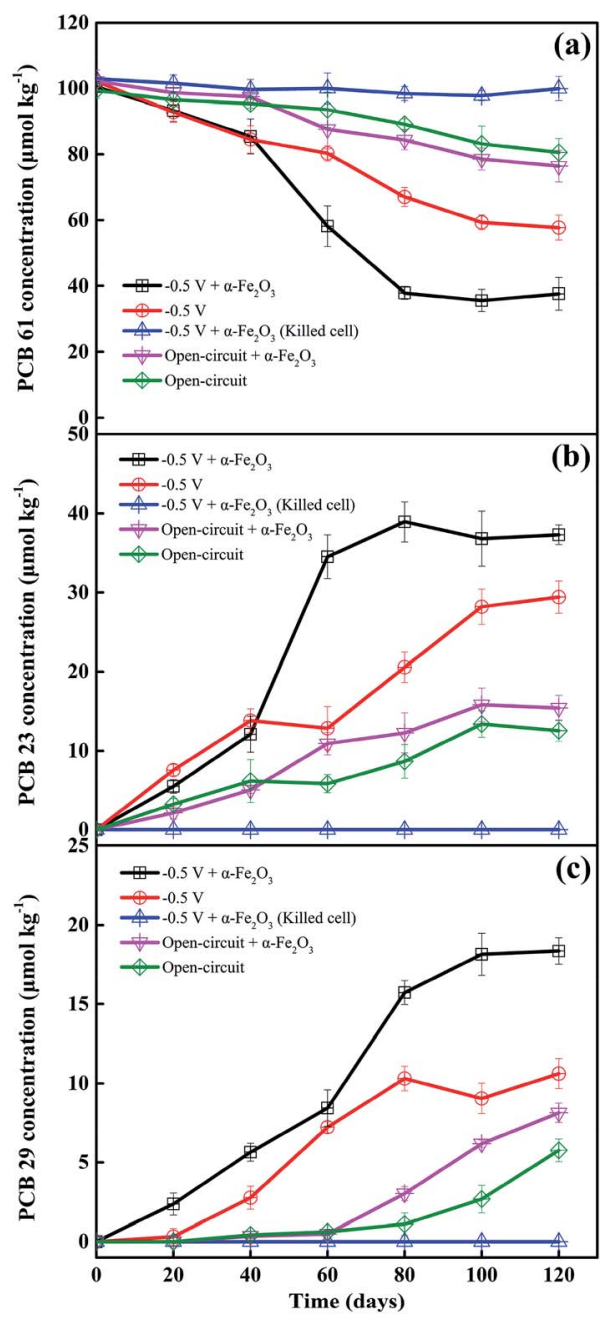

Fig. 1 Sediment concentrations of (a) PCB 61, (b) PCB 23 and (c) PCB 29 as a function of treatment time under different operation modes: error bars represent the standard deviation between duplicate microcosms. 
condition, there were insignificant variations in the concentration of PCB 61, suggesting that direct electrochemical reduction in this system was not kinetically favored. Appreciable disappearance of the parent PCB 61 was observed under other circumstances, and the concentration-time courses of PCB 61 reduction could be fitted with the pseudo-first-order rate law. The application of $-0.50 \mathrm{~V}$ to the electrode remarkably enhanced PCB 61 reduction, as $43.5 \pm 3.7 \%$ of PCB 61 disappeared in 120 days. The fraction of PCB 61 transformation further increased to $62.5 \pm 4.9 \%$ in the BER with amendment of $\alpha-\mathrm{Fe}_{2} \mathrm{O}_{3}$. The corresponding rate constant increased from $(5.1 \pm$ $0.3) \times 10^{-3} \mathrm{~d}^{-1}$ to $(10.2 \pm 1.5) \times 10^{-3} \mathrm{~d}^{-1}$ as a consequence of $\alpha$ $\mathrm{Fe}_{2} \mathrm{O}_{3}$ addition. This improvement was significant in the pairedsamples $t$-test $(p<0.05)$. In contrast, the rate constant of PCB 61 reduction in the open-circuit reactor with $\alpha-\mathrm{Fe}_{2} \mathrm{O}_{3}$ addition was $(2.5 \pm 0.2) \times 10^{-3} \mathrm{~d}^{-1}$, which was not significantly different from the result $(1.8 \pm 0.2) \times 10^{-3} \mathrm{~d}^{-1}$ obtained from the identical reactor in the absence of $\alpha-\mathrm{Fe}_{2} \mathrm{O}_{3}(p>0.05)$. This indicates that the presence of $\alpha-\mathrm{Fe}_{2} \mathrm{O}_{3}$ has insignificant impact on PCB 61 reduction in the open-circuit reactor that was working analogously to the traditional anaerobic biochemical reactor (ABR). The result was contradictory to previous results reporting the inhibitory effect of iron oxides on bioreduction of contaminants due to the competition for electron donors. ${ }^{8}$ This could be explained by the fact that $\alpha-\mathrm{Fe}_{2} \mathrm{O}_{3}$ and PCB 61 did not become competitive electron acceptors because excess electron donors were provided. In addition, there was possibility that insufficient amounts of $\mathrm{Fe}(\mathrm{II})$ were generated in the open-circuit circumstance, thereby displaying limited reactivity towards PCB 61 reduction.

Fig. $1 \mathrm{~b}$ and c shows that PCB 23 and PCB 29 are the two main dechlorination products under all the cases with bacteria being involved in PCB 61 reduction. This suggests that the doubleflanked para- and meta-dechlorination are the dominant pathways, which agree with previously reported data concerning microbial reduction of PCBs under anaerobic conditions. ${ }^{\mathbf{1 4 , 1 5}}$ Comparisons of the concentration-time courses of PCB 23 and PCB 29 production between the different treatments showed that the greater amounts of PCB 23 and PCB 29 produced were closely related to the larger amounts of PCB 61 reduced. For example, the 120 day operation results in the production of 37.3 $\pm 1.22 \mu \mathrm{mol} \mathrm{kg}{ }^{-1}$ PCB 23 in the poised BER with $\alpha-\mathrm{Fe}_{2} \mathrm{O}_{3}$ addition. This value was 1.27 times larger than that obtained in the absence of $\alpha-\mathrm{Fe}_{2} \mathrm{O}_{3}$. It should be noteworthy that the concentration of PCB 23 was larger than that of PCB 29 under all the circumstances, indicating that PCB dechlorination in sediments proceeded primarily at the double-flanked para-position rather than at the meta-position, consistent with previous findings. ${ }^{24}$ Negligible concentrations of PCB 9 were detected under all the conditions.

\subsection{Variations in bacterial community structures in response to electrical stimulation and iron oxide amendment}

Analysis of bacterial community structures was performed to explain the variations in the extent and rate of PCB 61 dechlorination as a result of electrical stimulation and $\alpha-\mathrm{Fe}_{2} \mathrm{O}_{3}$ addition. The tested samples included the seed sediment (S0), and other four samples consisting of sediments and cathode materials (i.e., graphite particles and graphite felt), referred to those taken from the closed-circuit BERs with (S1) and without (S2) $\alpha-\mathrm{Fe}_{2} \mathrm{O}_{3}$ addition, as well as the open-circuit reactors in the presence (S3) and absence (S4) of $\alpha-\mathrm{Fe}_{2} \mathrm{O}_{3}$. The samples in duplicate were also subjected to bacterial analysis, being denoted as $\mathrm{S}^{\prime}$ to $\mathrm{S}^{\prime}$, respectively. Fig. 2 shows the PCA results, with PC1 and PC2 explaining 53.8\% and $13.1 \%$ of the variations in the community structure, respectively. Note that the bacterial community structures were highly similar between the duplicate samples under all the cases. It was apparent that the inoculated samples were located far away from the seed samples ( $\mathrm{S} 0$ and $\mathrm{SO}^{\prime}$ ), suggesting a remarkable shift in the bacterial composition after enrichment. The amendment of $\alpha$ $\mathrm{Fe}_{2} \mathrm{O}_{3}$ might largely influence the bacterial structures under the closed-circuit conditions, as evident from the separate location between $\mathrm{S} 1$ (S1') and $\mathrm{S} 2\left(\mathrm{~S} 2^{\prime}\right)$ samples. On the contrary, its impact on the bacterial structure under the open-circuit conditions was notably lower; the close distance between S3 $\left(\mathrm{S}^{\prime}\right)$ and $\mathrm{S} 4\left(\mathrm{~S}^{\prime}\right)$ was observed, an indicative of sufficient similarities of their bacterial compositions. It thus can be inferred that the addition of $\alpha-\mathrm{Fe}_{2} \mathrm{O}_{3}$ makes the difference in the PCB dechlorination kinetics and induces the shift of bacterial community when there is electric field stimulation, but exerts little impact when no electric fields are applied.

The dominant genera with relative abundance over $2 \%$ were identified to show the variations in the bacterial structures in relation to the enrichments with electrical stimulation and $\alpha$ $\mathrm{Fe}_{2} \mathrm{O}_{3}$ addition. Table 1 displays the genus-level results of the S0, S1, S2, S3 and S4 samples. It was revealed that the seed sediment (S0) exhibited a wide range of bacterial diversity, with no specific genera having an abundance larger than $2 \%$. The remarkable differences between the enriched samples are summarized as follows. (i) The genera Geobacter and Desulfovibrio were distinctly detected in the samples taken from the

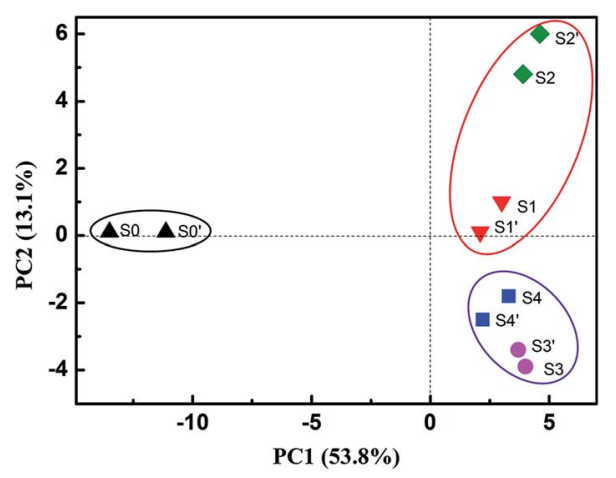

Fig. 2 Principle component analysis (PCA) of bacterial communities based on the classified OTUs (PC1 $=58.3 \%$, PC2 = 13.1\%). SO and SO' (replicate sample): the seed sediment; $\mathrm{S} 1$ and $\mathrm{S}^{\prime}$ (replicate sample): the sediment of the BER with $\alpha-\mathrm{Fe}_{2} \mathrm{O}_{3}$ addition; $\mathrm{S} 2$ and $\mathrm{S}^{\prime}$ (replicate sample): the sediment of the BER without $\alpha-\mathrm{Fe}_{2} \mathrm{O}_{3}$ addition; $\mathrm{S} 3$ and $\mathrm{S}^{\prime}$ (replicate sample): the sediment of the open-circuit reactor with $\alpha$ $\mathrm{Fe}_{2} \mathrm{O}_{3}$ addition; and $\mathrm{S} 4$ and $\mathrm{S}^{\prime}$ (replicate sample): the sediment of the open-circuit reactor without $\alpha-\mathrm{Fe}_{2} \mathrm{O}_{3}$ addition. 
Table 1 Phylogenetic classification of the 16S rRNA gene sequences (relative abundance $>2 \%$ at genus level) in sediment samples. S0: the seed sediment; S1: the sediment of the BER with $\alpha-\mathrm{Fe}_{2} \mathrm{O}_{3}$ addition; S2: the sediment of the BER without $\alpha-\mathrm{Fe}_{2} \mathrm{O}_{3}$ addition; S3: the sediment of the open-circuit reactor with $\alpha-\mathrm{Fe}_{2} \mathrm{O}_{3}$ addition; and S4: the sediment of the open-circuit reactor without $\alpha$ - $\mathrm{Fe}_{2} \mathrm{O}_{3}$ addition

\begin{tabular}{|c|c|c|c|c|c|c|c|c|}
\hline No. & Phylum & Class & Genus & So & $\mathrm{S} 1$ & S2 & S3 & S4 \\
\hline 1 & Proteobacteria & Deltaproteobacteria & Geobacter & 1.73 & 17.96 & 2.20 & 0.01 & 0.00 \\
\hline 2 & Euryarchaeota & Methanomicrobia & Methanosaeta & 1.61 & 9.29 & 7.68 & 0.68 & 5.15 \\
\hline 4 & Proteobacteria & Gammaproteobacteria & Methylomicrobium & 0.02 & 2.58 & 2.09 & 1.44 & 0.93 \\
\hline 5 & Proteobacteria & Betaproteobacteria & Hydrogenophaga & 0.06 & 4.11 & 14.95 & 33.58 & 24.04 \\
\hline 6 & Bacteroidetes & Bacteroidia & Blvii28 & 0.18 & 1.09 & 1.47 & 2.60 & 1.81 \\
\hline 9 & Firmicutes & Clostridia & Clostridium & 0.98 & 1.37 & 1.57 & 1.20 & 2.01 \\
\hline
\end{tabular}

closed-circuit BERs. In addition, the additional $\alpha-\mathrm{Fe}_{2} \mathrm{O}_{3}$ had a remarkable effect on their amounts, as the abundances of Geobacter and Desulfovibrio increased from $2.20 \%$ and $1.26 \%$ in S2 to $17.96 \%$ and $3.21 \%$ in S1, respectively. Many previous reports have demonstrated that Geobacter and Desulfovibrio are capable of growing as a result of acetate oxidation coupled to the reduction of electrode or iron oxide, causing the production of biocurrent. ${ }^{25,26}$ The detection of these electrode-respiring bacteria (ERB) is explainable due to the potential difference between the applied potential $(-0.50 \mathrm{~V})$ and the redox potential of acetate oxidation $(-0.56 \mathrm{~V})$. It was documented that the Geobacter and Desulfovibrio species can also function as the facultative dechlorinating bacteria driving the reduction of PCBs and other chlorinated compounds with $\mathrm{H}_{2}$, acetate and a variety of small-molecule organic acids as the electron donors. ${ }^{27,28}$ The ERB such as Geobacter and Desulfovibrio are also known as dissimilatory iron-reducing bacteria (DIRB) able to respire with iron oxides as the terminal electron acceptors..$^{29,30}$ (ii) The dominant genus enriched from the open-circuit reactors was Hydrogenophaga whose abundance in S3 and S4 was 33.58\% and $24.04 \%$, respectively, much higher than that in S1 (4.11\%) and S2 (14.95\%). This species has been reported to dechlorinate PCBs coupled to the oxidation of $\mathrm{H}_{2} .{ }^{31}$ The fermenting bacteria involved in the decomposition of acetate to $\mathrm{H}_{2}$ were also notably detected. These included genera Blvii28, ${ }^{32}$ Kosmotoga, ${ }^{33}$ and Syntrophobacter. ${ }^{34}$ (iii) Of particular interest was the discovery of genera Methanosaeta and Methylomicrobium, which are more abundant in S1 and S2 than in S3 and S4. The function of these bacteria in the BERs remains unknown despite their coexistence with Geobacter. It has been reported that Geobacter and Methanosaeta species can exchange electrons via direct interspecies electron transfer. $^{35}$ The Methanosaeta species might compete with Geobacter for electrons donated by acetate; they might also have the possibility to enhance dechlorination. ${ }^{36}$ The genus Methylomicrobium belongs to the Methanotrophs showing the uniqueness in degrading halogenated hydrocarbons. ${ }^{37}$

\subsection{Determination of current and biogenic $\mathrm{Fe}$ (II) produced in the system}

It has been demonstrated in the literature ${ }^{38-40}$ that iron oxides can play a significant role in the growth of ERB, enhancing extracellular electron transfer process between the microbes and electrode, and thus promoting current production. Fig. 3a presents that the addition of $\alpha-\mathrm{Fe}_{2} \mathrm{O}_{3}$ causes a pronounced increase in the current generated by biooxidation of acetate. For example, the maximum current with the amendment of $\alpha-\mathrm{Fe}_{2} \mathrm{O}_{3}$ was $3.18 \pm 0.13 \mathrm{~mA}$, increased by 2.43 times compared to that obtained without the amendment after 120-day incubation. The iron oxide-mediated electron transfer mechanism was depicted in our previous report: ${ }^{39}$ acetate was oxidized to $\mathrm{CO}_{2}$ coupled to the reduction of iron oxides by DIRB such as Geobacter and Desulfovibrio, resulting in the formation of Fe(II) bound to iron oxides, which was immediately oxidized by the electrode.

Dissimilatory iron reduction by DIRB utilizing iron oxides as the terminal electron acceptors is a prevalent process in anaerobic subsurface environments. ${ }^{30}$ The enrichment of highabundance DIRB was found to boost the formation of biogenic $\mathrm{Fe}(\mathrm{II}) .{ }^{10}$ Concentrations of biogenic $\mathrm{Fe}(\mathrm{II})$ that was expressed in the form of HCl-extracted Fe(II) including the dissolved and adsorbed Fe(II). It should be noted that after 60-day enrichment, the concentrations of adsorbed $\mathrm{Fe}(\mathrm{II})$ in each reactors were ranged from $9.25 \pm 0.61$ to $26.42 \pm 0.93 \mathrm{mmol} \mathrm{L}^{-1}$; and those of dissolved $\mathrm{Fe}(\mathrm{II})$ and $\mathrm{Fe}(\mathrm{III})$ were about $0.18 \pm 0.02$ and $0.09 \pm$ $0.01 \mathrm{mmol} \mathrm{L}^{-1}$, respectively. These results indicate that the biogenic $\mathrm{Fe}(\mathrm{II})$ mainly existed in the adsorbed form. The concentrations of biogenic adsorbed $\mathrm{Fe}$ (II) were plotted against incubation time and illustrated in Fig. 3b. Longer incubation time led to the increase in the adsorbed Fe(II) content, consistent with the ascending trends of current (Fig. 3a). Note that higher amounts of $\mathrm{Fe}(\mathrm{II})$ were detected in the BER system with the addition of $\alpha-\mathrm{Fe}_{2} \mathrm{O}_{3}$ as compared to other reference experiments. After 120 day incubation, the biogenic adsorbed $\mathrm{Fe}(\mathrm{II})$ content in the $\alpha-\mathrm{Fe}_{2} \mathrm{O}_{3}$-amended BER was $23.92 \pm 1.41 \mathrm{mmol}$ $\mathrm{L}^{-1}$, larger than $15.39 \pm 1.08 \mathrm{mmol} \mathrm{L}^{-1}$ produced in the same system without $\alpha-\mathrm{Fe}_{2} \mathrm{O}_{3}$ amendment. The certain amount of biogenic adsorbed $\mathrm{Fe}(\mathrm{II})$ detected in the system without additional $\alpha-\mathrm{Fe}_{2} \mathrm{O}_{3}$ confirmed the availability of iron minerals naturally in the sediment. The application of an electrical field stimulated the growth of DIRB, ${ }^{38-40}$ which in turn caused the increased amounts of biogenic $\mathrm{Fe}(\mathrm{II})$. This was evident from the higher concentrations of biogenic adsorbed Fe(II) achieved in the BERs than those obtained from the open-circuit reactors (Fig. 3b). 

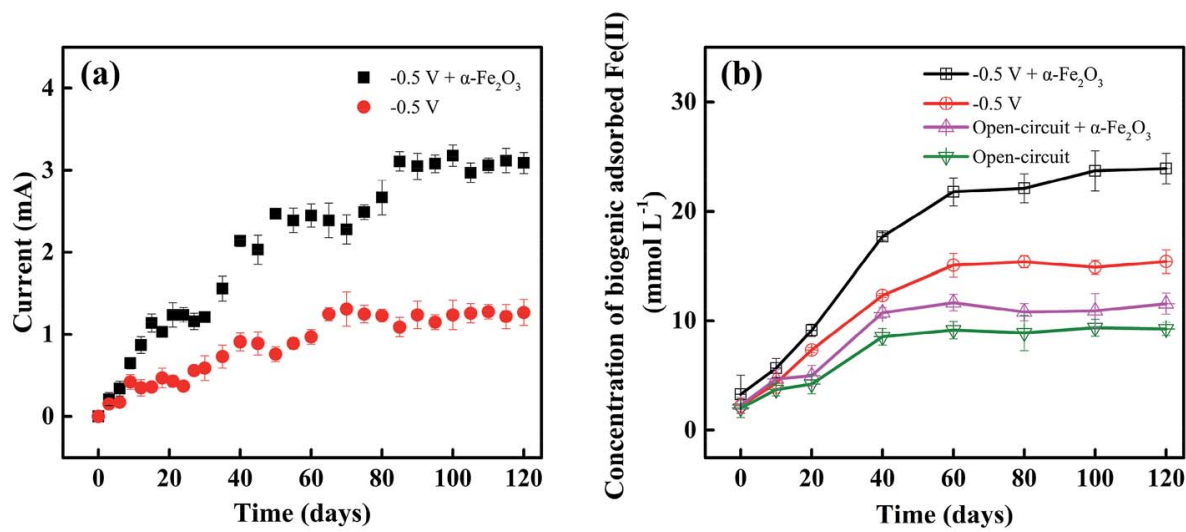

Fig. 3 (a) Current and (b) biogenic adsorbed Fe(॥) concentration as a function of treatment time under different operation modes: error bars represent the standard deviation between duplicate microcosms.

\subsection{Possible mechanisms governing PCB dechlorination in the BERs available with iron oxides}

The kinetic data provided compelling evidence that the availability of iron oxides was effective in enhancing the extent and rate of PCB 61 dechlorination in the BERs poised at a potential of $-0.50 \mathrm{~V}$. Attempts were made to understand possible mechanisms governing PCB dechlorination under such a case by combining the kinetic data with the bacterial analysis results. Taking acetate as an example of electron donor and considering the poised potential of $-0.50 \mathrm{~V}$ to the electrode, possible reactions occurring in the BES are classified into the following categories.

(1) Biological reactions:

$$
4 \square \mathrm{Q}_{\mathrm{c}_{n}}+\mathrm{CH}_{3} \mathrm{COO}^{-}+2 \mathrm{H}_{2} \mathrm{O} \stackrel{\text { bacteria }}{\longrightarrow} 4 \square-\mathrm{V}_{\mathrm{c}_{\mathrm{m}}}+2 \mathrm{CO}_{2}+3 \mathrm{H}^{+}+4 \mathrm{Cl}^{-}
$$

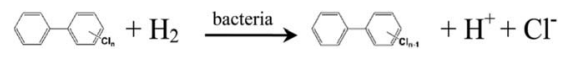

$$
\begin{aligned}
& 4 \mathrm{Fe}_{2} \mathrm{O}_{3}+\mathrm{CH}_{3} \mathrm{COO}^{-}+15 \mathrm{H}^{+} \stackrel{\text { bacteria }}{\longrightarrow} \\
& 8 \mathrm{Fe}^{2+}+2 \mathrm{HCO}_{3}^{-}+8 \mathrm{H}_{2} \mathrm{O}
\end{aligned}
$$

These reactions take place in the BES as analogous to the traditional anaerobic reduction system, with PCB dechlorination coupled to the oxidation of acetate via the heterotrophic bacteria (reaction (1) $)^{41}$ or fermented hydrogen via the autotrophic bacteria (reaction (2)). ${ }^{42}$ Iron oxides can function as the terminal electron acceptors mediated by the dissimilatory ironreducing bacteria, resulting in the formation of dissolved $\mathrm{Fe}$ (II) (reaction (3)). ${ }^{29,30}$

(2) (Electro)chemical reactions:

$$
\square\left\langle\nabla_{\mathrm{c}_{0}}+2 \mathrm{Fe}^{2+}+\mathrm{H}^{+} \longrightarrow \mathrm{Cl}_{\mathrm{ln}}+\mathrm{Cl}^{-}+2 \mathrm{Fe}^{3+}\right.
$$

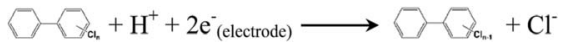

The biogenic adsorbed $\mathrm{Fe}(\mathrm{II})$ species, which represent important reductants for the abiotic transformation of many sediment and soil contaminants, ${ }^{7}$ should possibly drive the reduction of PCBs according to reaction (4). Because the applied potential $(-0.50 \mathrm{~V})$ is substantially lower than the redox potential ( $0.64 \mathrm{~V}$ vs. SHE, standard hydrogen electrode) of PCBs, ${ }^{43}$ direct electrochemical reduction of PCBs, from the thermodynamic view, may occur (reaction (5)).

(3) Bioelectrochemical reactions:

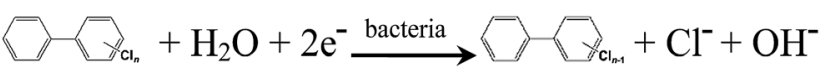

$$
\mathrm{CH}_{3} \mathrm{COO}^{-}+2 \mathrm{H}_{2} \mathrm{O} \stackrel{\text { bacteria }}{\longrightarrow} 2 \mathrm{CO}_{2}+7 \mathrm{H}^{+}+8 \mathrm{e}^{-}
$$

Under the application of $-0.50 \mathrm{~V}$, direct PCB reduction might proceed with cathodophilic bacteria as the biocatalysts (reaction (6)). These are autotrophic microorganisms able to use cathodes directly as electron donors, playing a vital role in dechlorination. ${ }^{\mathbf{4 4}}$ It should be noted that the applied potential $(-0.50 \mathrm{~V})$ is larger than the redox potential $(-0.55 \mathrm{~V})$ of acetate at $\mathrm{pH}$ 7.0, anodic oxidation of acetate might occur with the electrode as the electron acceptor via the anode-respiring bacteria (reaction (7)). ${ }^{45}$ Previous studies have demonstrated the $\alpha$ - $\mathrm{Fe}_{2} \mathrm{O}_{3}$-mediated anodic electron transfer in which the presence of iron oxide is responsible for the increased numbers of cells, the enhanced electron transfer rate, and the increase in current generation. ${ }^{38,39}$

The correlations between the rate constant of PCB 61 reduction in Fig. 1 and the data of current and adsorbed $\mathrm{Fe}$ (II) concentration in Fig. 3 should provide information on which reactions should predominantly contribute to PCB dechlorination in the system. To make the statistical analysis reliable, additional sets of experiments with amendment of other iron 
oxides, such as $\alpha$-FeOOH, $\gamma$-FeOOH and $\gamma-\mathrm{Fe}_{2} \mathrm{O}_{3}$ were conducted and the relevant data was collected. As can be seen from Fig. 4a, the rate constant was positively correlated to the concentration of biogenic adsorbed Fe(II), suggesting the role of adsorbed Fe(II) in PCB dechlorination. A linear relationship was also revealed between the rate constant and the current (Fig. 4b). This is understandable given our previous finding of the linear correlation between the current and the concentration of adsorbed Fe(II), as revealed in a similar DIRB-driven BER but without the spiked PCBs. ${ }^{39}$ In addition, both the concentration of biogenic adsorbed $\mathrm{Fe}(\mathrm{II})$ and the current were positively correlated with the surface area of iron oxides in the increasing order of $\alpha-\mathrm{FeOOH}>\gamma-\mathrm{FeOOH}>\alpha-\mathrm{Fe}_{2} \mathrm{O}_{3}>\gamma-\mathrm{Fe}_{2} \mathrm{O}_{3}$, in accordance with the findings obtained from the phosphate buffer solution in previous reports. ${ }^{39,46}$ These correlations suggest that the enhanced РСB dechlorination as a consequence of iron oxide amendment should be benefited from the more amounts of adsorbed Fe(II) produced; that is, the abiotic reaction between Fe(II) and PCBs (reaction (4)) should be the main contributor to dechlorination.

It was evident from the microbial community data (Table 1) that no obligate organohalide-respiring bacteria (OHRB), such as Dehalococcoides, ${ }^{15,47}$ Dehalobium ${ }^{16}$ and Dehalobacter ${ }^{47}$ were distinctly detected in the system. Although it was documented that the highly abundant Geobacter and Desulfovibrio species can function as the facultative OHRB driving the reduction of relatively easily dechlorinated compounds such as tetrachloroethene and pentachlorophenol, ${ }^{27,28}$ the ability of these species to dechlorinate PCBs remains unknown. In comparison
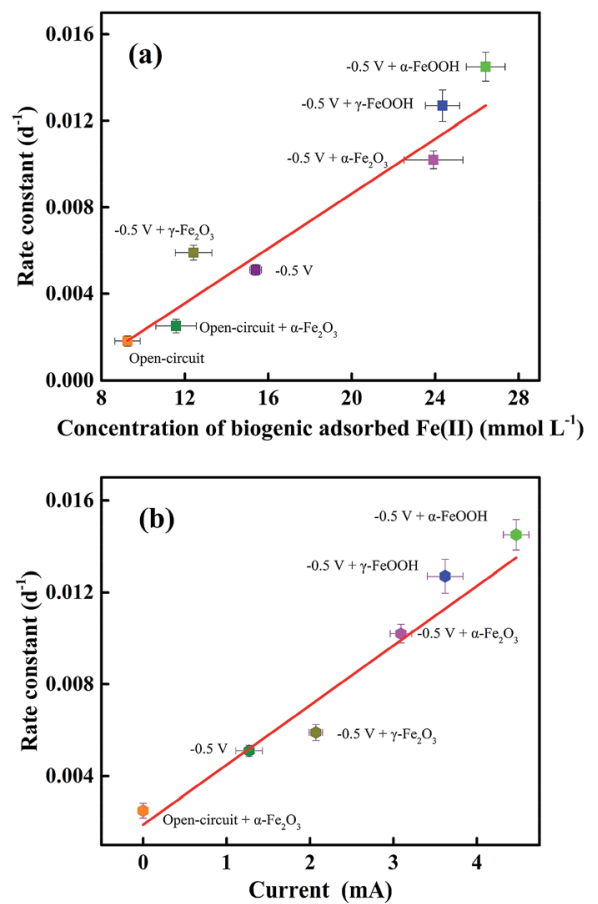

Fig. 4 Dependence of the rate constant of PCB 61 dechlorination on (a) the concentration of biogenic adsorbed Fe(॥) and (b) the value of current. The data sets of $\mathrm{Fe}(॥)$ concentration and current were collected after 120-day incubation. to the abiotic reaction (Fe(II)-mediated) (reaction (4)), the biotic reaction (cell-mediated) (reaction (1)) should be a less significant factor for PCB dechlorination. In addition, direct electrochemical reduction of PCB 61 with the applied potential of $-0.50 \mathrm{~V}$ did not occur (reaction (5)), as reflected by the insignificant changes in its concentration in the killed-cell reference reactor. Bioelectrochemical reduction of PCB 61 might also not occur under this case, because no cathodic currents were displayed (reaction (6)).

On the whole, we propose possible mechanisms predominantly contributing to PCB dechlorination under the circumstance of electrical stimulation and in the presence of iron oxides. As depicted by Fig. 5a, the application of an electrical field enables the generation of bioelectricity via enrichment of ERB, which are able to catalyze the biooxidization of organic substrate (reaction (7)). This bioelectrochemical process is mediated by iron oxides that promote the growth of Geobacter and Desulfovibrio and boost bioelectricity generation..$^{38-40}$ These species, also known as DIRB, able to respire with iron oxides as electron acceptors (reaction (3)) and thus in turn result in the enhanced amounts of biogenic Fe(II). ${ }^{10}$ The reactive adsorbed $\mathrm{Fe}(\mathrm{II})$ bound to iron oxides has the ability of dechlorination (reaction (4)) and should be the predominant contributor to $\mathrm{PCB}$ reduction in the system. It should be noted that under the open-circuit conditions, the dechlorination of PCB 61 should mainly proceed with the help of Hydrogenophaga using fermented $\mathrm{H}_{2}$ as the electron donor (reaction (2)).

In addition, it has been previously proposed that the semiconductor-mediated electron transfer might contribute to the enhanced reduction of electron acceptors (including the electrode and the pollutants with high redox potential) via the interconnected bacterial network, when the addition of iron oxides was effective in accelerating extracellular electron transfer rates. ${ }^{48,49}$ This semiconductor-mediated mechanism might also be involved in electron transfer from the organic
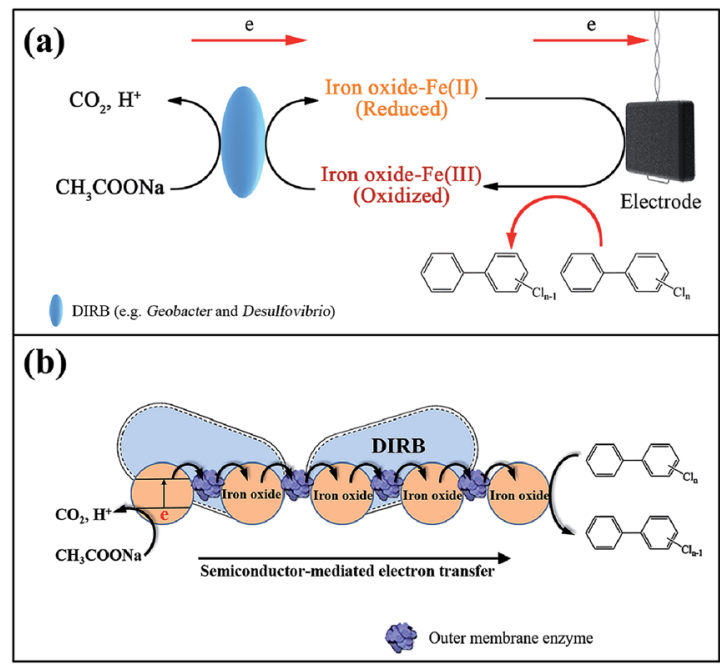

Fig. 5 Proposed possible mechanisms governing PCB dechlorination in the BERs available with iron oxides. (a) Biogenic adsorbed Fe(॥)mediated electron transfer mechanism, (b) semiconductor-mediated electron transfer mechanism. 
substrate to PCBs in such a complicated system, but deserves further in-depth investigations in the future. Fig. 5b illustrates the electrons transferred from the microbes to iron oxides, and further to PCBs. From thermodynamic point of view, the electron transfer process can exist at the interface of outer membrane enzyme (OME), because the conduction band of iron oxides (e.g., $-0.133 \mathrm{~V} v$ s. SHE for $\mathrm{Fe}_{2} \mathrm{O}_{3}$ and $+0.167 \mathrm{~V} v$ s. SHE for $\mathrm{FeOOH})$ is higher than the redox potential of the OME $(-0.20 \mathrm{~V}$ vs. SHE) of the DIRB (e.g., Geobacter). ${ }^{49}$ Likewise, further electron transfer can occur between the conduction band of iron oxides and the terminal electron acceptors, PCBs, with a redox potential of around $0.64 \mathrm{~V} v s$. SHE. ${ }^{43}$

\subsection{Environmental implications}

It has been reviewed in a previous pioneering publication ${ }^{50}$ concluding that in situ biotreatment is advantageous over the currently predominant ex situ treatment (i.e., dredging) for remediation of PCBs-contaminated sediments, in terms of environmental sustainability and low cost. Anaerobic microbial dechlorination of highly chlorinated congeners is recognized to be an important step in decreasing their toxicity and thus increasing their degradability, making them more susceptible to the aerobic degradation. ${ }^{51}$ This sequential anaerobic and aerobic method has been demonstrated to be effective in degrading PCBs. ${ }^{52}$ However, the anaerobic dechlorination of PCBs usually proceeds at a very low rate in natural environments. Many attempts have been devoted in developing biostimulation and/or bioaugmentation approaches for improving anaerobic dechlorination of weathered and spiked PCBs. For example, biostimulation of indigenous PCB-dechlorinating bacteria has been attained with halogenated aromatic compounds as the haloprimers to facilitate PCB dechlorination. ${ }^{2}$ Biostimulation with the addition of Fe was also effective in stimulating indigenous populations of PCB-dechlorinating bacteria, because Fe functioned as the source for releasing hydrogen that was utilized as the electron donor. ${ }^{53} \mathrm{~A}$ recent study has shown that granular activated carbon (GAC) can effectively be used to sequestrate PCBs and remarkably cause a community shift to organohalide respiring bacteria, which eventually promoted the transformation of higher to less chlorinated congeners. ${ }^{54}$ These approaches, despite their uniqueness of enhancing PCB dechlorination, should have the main drawback of periodic additions of chemicals that may be costly and cause secondary pollution. Here we provide a cost-effective and environmentally sustainable alternative by applying lowvoltage electrical fields to stimulate PCB dechlorination. This offers advantages with respect to a controlled supply of electrons for microbial metabolism. ${ }^{5}$ More importantly, we demonstrate the findings that the electrical stimulation can be efficiently coupled to the dissimilatory iron reducing process, further accelerating PCB reduction. Because of the large abundance of iron oxides contained in the sediments and soils in South China, our findings might indicate a promising in situ bioremediation technology for the dechlorination of PCBs in the contaminated sites by applying low-voltage electric fields. For future perspectives, this prompts a great impetus to investigate the effect of various naturally iron minerals on the enhancement of dechlorination of PCBs as well as other chlorinated compounds in the contaminated sites by electrical stimulation. Profound mechanistic understanding is also needed to optimize the potential poised to the electrode, because the applied potential substituting the potential of a chemical electron donor or acceptor determines the energy for bacterial metabolism, ${ }^{55}$ thus the rate and the extent of bioelectrochemical dechlorination. ${ }^{6}$

\section{Conclusions}

The present study demonstrated that the availability of iron oxides was essential for enhancing PCB dechlorination in the sediment-based BERs. The DIRB such as Geobacter and Desulfovibrio species with high abundances were dominantly enriched in the BERs in the presence of iron oxides. Analysis of correlation between the rate constant of PCB 61 reduction and the biogenic adsorbed Fe(II) concentration suggested that the increasing amounts of $\mathrm{Fe}(\mathrm{II})$ generated from the dissimilatory iron reduction process should predominantly contribute to the enhanced PCB dechlorination.

\section{Acknowledgements}

We gratefully acknowledge financial support from the National Natural Science Foundation of China (no. 51378216 and 21177042), the Natural Science Foundation of Guangdong Province, China (no. 2016A030311023), and the Fundamental Research Funds for the Central Universities, SCUT (project No. 2017ZD066).

\section{References}

1 K. R. Sowers and H. D. May, Curr. Opin. Biotechnol., 2013, 24, 482-488.

2 R. B. Payne, H. D. May and K. R. Sowers, Environ. Sci. Technol., 2011, 45, 8772-8779.

3 A. Leung, Z. W. Cai and M. H. Wong, J. Mater. Cycles Waste Manage., 2006, 8, 21-33.

4 X. Bi, G. O. Thomas, K. C. Jones, W. Qu, G. Sheng, F. L. Martin and J. Fu, Environ. Sci. Technol., 2007, 41, 5647-5653.

5 F. Aulenta, A. Canosa, P. Reale, S. Rossetti, S. Panero and M. Majone, Biotechnol. Bioeng., 2009, 103, 85-91.

6 F. Aulenta, L. Tocca, R. Verdini, P. Reale and M. Majone, Environ. Sci. Technol., 2011, 45, 8444-8451.

7 M. Chen, C. Liu, X. Li, W. Huang and F. Li, Soil Sci., 2014, 179, 457-467.

8 L. Paul, S. Herrmann, C. B. Koch, J. Philips and E. Smolders, Water Res., 2013, 47, 2543-2554.

9 M. L. McCormick, E. J. Bouwer and P. Adriaens, Environ. Sci. Technol., 2002, 36, 403-410.

10 M. Chen, H. Tong, C. Liu, D. Chen, F. Li and J. Qiao, Chemosphere, 2016, 160, 141-148.

11 Q. Zhao, J. Bai, Q. Lu, Z. Gao, J. Jia, B. Cui and X. Liu, Environ. Pollut., 2016, 213, 860-869. 
12 X. Wang, B. Xi, S. Huo, L. Deng, Q. Li, H. Pan, J. Zhang and H. Liu, Environ. Earth Sci., 2013, 71, 849-861.

13 Y. Jiang, X. Wang, K. Zhu, M. Wu, G. Sheng and J. Fu, Chemosphere, 2011, 83, 767-773.

14 L. J. Winchell and P. J. Novak, Chemosphere, 2008, 71, 176182.

15 T. Yan, T. M. LaPara and P. J. Novak, FEMS Microbiol. Ecol., 2006, 55, 248-261.

16 N. J. Lombard, U. Ghosh, B. V. Kjellerup and K. R. Sowers, Environ. Sci. Technol., 2014, 48, 4353-4360.

17 F. Li, X. Wang, C. Liu, Y. Li, F. Zeng and L. Liu, Geoderma, 2008, 148, 70-78.

18 H. Yu, C. Feng, X. Liu, X. Yi, Y. Ren and C. Wei, Environ. Pollut., 2016, 211, 81-89.

19 D. Xie, H. Yu, C. Li, Y. Ren, C. Wei and C. Feng, Electrochim. Acta, 2014, 133, 217-223.

20 D. Liu, L. Lei, B. Yang, Q. Yu and Z. Li, Bioresour. Technol., 2013, 148, 9-14.

21 H. Yu, H. Wan, C. Feng, X. Yi, X. Liu, Y. Ren and C. Wei, Sci. Total Environ., 2017, 580, 1371-1380.

22 J. K. Fredrickson, J. M. Zachara, D. W. Kennedy, H. L. Dong, T. C. Onstott, N. W. Hinman and S. M. Li, Geochim. Cosmochim. Acta, 1998, 62, 3239-3257.

23 F. Picardal, R. G. Arnold and B. B. Huey, Appl. Environ. Microbiol., 1995, 61, 8-12.

24 L. Adrian, V. Dudkova, K. Demnerova and D. L. Bedard, Appl. Environ. Microbiol., 2009, 75, 4516-4524.

25 C. S. Kang, N. Eaktasang, D. Y. Kwon and H. S. Kim, Bioresour. Technol., 2014, 165, 27-30.

26 A. E. Rotaru, T. L. Woodard, K. P. Nevin and D. R. Lovley, Front. Microbiol., 2015, 6, 744.

27 Z. L. Li, J. Nan, C. Huang, B. Liang, W. Z. Liu, H. Y. Cheng, C. Zhang, D. Zhang, D. Kong, K. Kanamaru, T. Kobayashi, A. J. Wang and A. Katayama, Sci. Rep., 2016, 6, 19015.

28 Y. Sung, K. E. Fletcher, K. M. Ritalahti, R. P. Apkarian, N. Ramos-Hernandez, R. A. Sanford, N. M. Mesbah and F. E. Loffler, Appl. Environ. Microbiol., 2006, 72, 2775-2782.

29 D. R. Lovley, E. E. Roden, E. Phillips and J. Woodward, Mar. Geol., 1993, 113, 41-53.

30 D. R. Lovley, D. E. Holmes and K. P. Nevin, Adv. Microb. Physiol., 2004, 49, 219-286.

31 A. Lambo and T. Patel, J. Appl. Microbiol., 2007, 102, 13181329.

32 X. L. Su, Q. Tian, J. Zhang, X. Z. Yuan, X. S. Shi, R. B. Guo and Y. L. Qiu, Int. J. Syst. Evol. Microbiol., 2014, 64, 2986-2991.

33 X. Jiang, J. Shen, Y. Han, S. Lou, W. Han, X. Sun, J. Li, Y. Mu and L. Wang, Water Res., 2016, 88, 257-265.
34 H. Satoh, I. Tsushima, Y. Miura, T. Ito and S. Okabe, Water Sci. Technol., 2012, 65, 2125-2131.

35 A.-E. Rotaru, P. M. Shrestha, F. Liu, M. Shrestha, D. Shrestha, M. Embree, K. Zengler, C. Wardman, K. P. Nevin and D. R. Lovley, Energy Environ. Sci., 2014, 7, 408-415.

36 G. L. Heavner, A. R. Rowe, C. B. Mansfeldt, J. K. Pan, J. M. Gossett and R. E. Richardson, Environ. Sci. Technol., 2013, 47, 3724-3733.

37 J. I. Han, S. Lontoh and J. D. Semrau, Arch. Microbiol., 1999, 172, 393-400.

38 R. Nakamura, F. Kai, A. Okamoto, G. J. Newton and K. Hashimoto, Angew. Chem., Int. Ed., 2009, 48, 508-511.

39 C. Feng, X. Yue, F. Li and C. Wei, Biosens. Bioelectron., 2013, 39, 51-56.

40 S. Zhou, J. Tang and Y. Yuan, Bioelectrochemistry, 2015, 102, 29-34.

41 D. L. Bedard, K. M. Ritalahti and F. E. Loffler, Appl. Environ. Microbiol., 2007, 73, 2513-2521.

42 L. A. Cutter, J. E. M. Watts, K. R. Sowers and H. D. May, Environ. Microbiol., 2001, 3, 699-709.

43 J. Dolfing and I. Novak, Biodegradation, 2015, 26, 15-27.

44 L. Huang, J. M. Regan and X. Quan, Bioresour. Technol., 2011, 102, 316-323.

45 B. G. Lusk, P. Parameswaran, S. C. Popat, B. E. Rittmann and C. I. Torres, Bioelectrochemistry, 2016, 112, 47-52.

46 X. Li, T. Liu, F. Li, W. Zhang, S. Zhou and Y. Li, J. Soils Sediments, 2012, 12, 217-227.

47 S. Wang and J. He, Environ. Sci. Technol., 2013, 47, 1052610534.

48 W. Zhang, X. Li, T. Liu and F. Li, J. Soils Sediments, 2012, 12, 354-365.

49 T. Liu, X. Li, W. Zhang, M. Hu and F. Li, J. Colloid Interface Sci., 2014, 423, 25-32.

50 K. R. Sowers and H. D. May, Curr. Opin. Biotechnol., 2013, 24, 482-488.

51 D. A. Abramowicz, Environ. Health Perspect. , 1995, 103(5), 9799.

52 C. L. Chun, R. B. Payne, K. R. Sowers and H. D. May, Water Res., 2013, 47, 141-152.

53 H. I. Gomes, C. Dias-Ferreira, L. M. Ottosen and A. B. Ribeiro, J. Colloid Interface Sci., 2014, 433, 189-195.

54 B. V. Kjellerup, C. Naff, S. J. Edwards, U. Ghosh, J. E. Baker and K. R. Sowers, Water Res., 2014, 52, 1-10.

55 J. C. Thrash and J. D. Coates, Environ. Sci. Technol., 2008, 42, 3921-3931. 